\title{
PENINGKATAN HASIL BELAJAR SISWA PADA MATERI IKATAN KIMIA MELALUI PENERAPAN MODEL PEMBELAJARAN KOOPERATIF TIPE NUMBERED HEAD TOGETHER (NHT) BERBANTUAN MODUL DI KELAS X SMA NEGERI 10 AMBON
}

\author{
Dominggus Tahya', Vecky S. Paunno² \\ ${ }^{1}$ Departement of Chemistry-FKIP, Pattimura University Ambon
}

\section{ABSTRACT}

A research has been conducted to find out the improvement of student learning outcomes in chemical bonding material. Researchers apply the cooperative learning model type Numbered Head Together (NHT) with the help of modules, in class $X$ students of SMA Negeri 10 Ambon. The type of research was quantitative descriptive. Based on the research results obtained 12 students $(40 \%)$ get very good qualifications, 10 students (33.3\%) get good qualifications, 6 students (20\%) get enough qualifications, and 2 students $(6.7 \%)$ get less qualifications. The acquisition of $\mathrm{N}$-gain value are 18 students $(60 \%)$ in the high category and 12 students $(40 \%)$ are in the medium category. The results of the normalized gain score analysis of the average of all students amounted to 0.71 were in the high category. These results indicate that the application of the NHT (numbered heads together) cooperative learning model with the help of modules succeeded in improving student learning outcomes in all aspects (cognitive, affective, and psychomotor).

Keywords: Cooperative Learning Model, Numbered Head Together, Modules, Chemical Bonding, Learning Outcomes.

\section{ABSTRAK}

Telah dilakukan penelitian untuk mengetahui peningkatan hasil belajar siswa pada materi ikatan kimia. Peneliti menerapkan model pembelajaran kooperatif tipe Numbered Head Together (NHT) dengan bantuan modul, pada siswa kelas X SMA Negeri 10 Ambon. Tipe peneltian ini adalah deskriptif kuantitatif. Berdasarkan hasi penelitian diperoleh 12 siswa (40\%) mendapatkan kualifikasi sangat baik, 10 siswa (33.3\%) mendapatkan kualifikasi baik, 6 siswa (20\%) mendapatkan kualifikasi cukup, dan 2 siswa (6.7\%) mendapatkan kualifikasi kurang. Perolehan nilai N-gain adalah 18 siswa (60\%) berada pada kategori tinggi dan 12 siswa (40\%) berada pada kategori sedang. Hasil analisis skor gain ternormalisasi rata-rata seluruh siswa sebesar 0,71 berada pada kategori tinggi. Hasil ini menunjukan bahwa penerapan model pembelajaran kooperattf tipe NHT (numbered heads together) dengan bantuan modul berhasil meningkatkan hasil belajar siswa pada semuan aspek (kognitif, afektif, dan psikomotor).

Kata Kunci: Model Pembelajaran Kooperatif, Numbered Head Together, Modul, Ikatan Kimia, Hasil Belajar.

\section{PENDAHULUAN}

Perkembangan ilmu pengetahuan dan teknologi menuntut manusia mampu berkompetisi dengan mengembangkan potensi yang dimilikinya agar bisa hidup sejahtera. Potensi dalam diri seseorang dapat dikembangkan melalui pendidikan. Pendidikan adalah usaha sadar dan terencana untuk mewujudkan suasana belajar dan proses pembelajaran agar peserta didik secara aktif mengembangkan potensi dirinya untuk memiliki kekuatan spiritual keagamaan, pengendalian diri, kepribadian, kecerdasan, akhlak mulia, serta keterampilan yang diperlukan dirinya, masyarakat, bangsa dan negara (Kemendikbud 2013).

Menurut Kemendikbud (2013) salah satu mata pelajaran yang dipelajari di sekolah menengah atas adalah mata pelajaran kimia. Namun dalam pembelajaran kimia masih banyak siswa yang mengalami kesulitan, hal ini sejalan dengan pendapat Supardi yang menyatakan bahwa pelajaran kimia sering dihubungkan dengan kebosanan, keengganan, dan kegagalan bagi sebagian siswa. 
Kimia juga diklasifikasikan ke dalam kelompok mata pelajaran yang sulit dan abstrak sehingga banyak siswa takut untuk mempelajarinya (Supardi, 2010). Oleh karena itu dalam proses pembelajaran kimia, guru perlu meningkatkan efektivitasnya agar kualitas pembelajaran selalu terjaga dan hasil yang diharapkan dapat memenuhi tujuan pembelajaran yang telah ditetapkan (Manurung, 2013). Guru dalam melakukan kegiatan pembelajaran di sekolah dituntut melakukan perubahan dengan cara menggunakan berbagai model pembelajaran yang sesuai dengan karakteristik materi dan tujuan pembelajaran, sehingga dapat meningkatkan hasil belajar siswa. Jika model pembelajaran yang digunakan dalam kegiatan belajar mengajar dapat meningkatkan motivasi siswa untuk terus belajar. Hal ini yang akan menentukan keberhasilan dalam pencapaian tujuan belajar.

Berdasarkan hasil observasi dan wawancara peneliti dengan guru mata pelajaran kimia Kelas $\mathrm{X}$ SMA Negeri 10 Ambon, diketahui bahwa masih banyak siswa mengalami kesulitan dalam memahami materi atau konsep kimia. Salah satu konsep yang sulit dipahami adalah ikatan kimia. Dimana hasil belajar pada Tahun Ajaran 2017/2018 menunjukan bahwa siswa yang mencapai Kriteria Ketuntasam Minimal $(\mathrm{KKM}=75)$ adalah 57 persen. Hal ini merupakan suatu permasalahan yang perlu dicari solusinya agar hasil belajar kimia khususnya konsep ikatan kimia pada SMA Negeri 10 Ambon dapat ditingkatkan.

Setelah melakukan analisis terhadap karakateristik materi ikatan kimia, dan tujuan pembelajaran yang akan dicapai, maka salah satu model pembelajaran yang cocok diterapkan adalah model pembelajaran kooperatif tipe Numbered Head Together (NHT). Penerapan model pembelajaran kooperatif tipe NHT memberikan waktu yang lebih banyak kepada siswa untuk berdiskusi di dalam kelompoknya, dimana siswa dapat saling bertukar pikiran satu sama lain sehingga terjadi transfer pengetahuan (Retnani, 2014). Hal ini akan berdampak pada meningkatnya pemahaman siswa terhadap materi ikatan kimia yang bersifat abstrak. Selain itu, penggunaan modul dapat meningkatkan kemandirian siswa dalam belajar karena modul disusun secara sistematis untuk mencapai tujuan belajar. Penyusunan modul dapat disesuaikan dengan kebutuhan dan kondisi siswa sehingga diharapkan dapat meningkatkan minat baca siswa dan dapat meningkatkan prestasi belajar (Ningsih, 2012).

Penelitian yang dilakukan oleh Sulfiani (2016) menunjukkan bahwa penerapan mode pembelajaran kooperatif tipe NHT meningkatkan hasil belajar siswa Kelas XI IPA1 SMA Negeri 3 Watampone dari siklus I ke siklus II untuk materi sturuktur atom, sistem periodik unsur, dan bentuk molekul. Berdasarkan hasil penelitian, pada siklus I sebanyak $55,18 \%$ siswa tergolong dalam kategori tidak tuntas dan $44,82 \%$ siswa tergolong dalam kategori tuntas, pada siklus II jumlah siswa yang berada pada kategori tidak tuntas telah berkurang dengan persentase $20,69 \%$ sedangkan jumlah siswa yang berada pada kategori tuntas meningkat menjadi $79,31 \%$.

Hasil penelitian Septianingrum (2014) menunukkan bahwa penerapan model pembelajaran kooperatif tipe NHT disertai media tekateki silang berhasil meningkatkan kemampuan memori dan prestasi belajar kimia pada materi Sistem Koloid di Kelas XI IPA 2 SMA Negeri 2 Karanganyar. Peningkatan kemampuan memori dapat dilihat pada siklus I diperoleh $41,67 \%$ dan pada siklus II diperoleh $69,44 \%$. Sedangkan peningkatan prestasi belajar dapat dilihat dari hasil tes kognitif, afektif dan psikomotor dimana pada siklus I diperoleh hasil secara berturut-turut yaitu $33,33 \%$; $71,49 \%$ dan $69,44 \%$ dan pada siklus II hasil tes kognitif $72,22 \%$.

Hasil penelitian Anggraini (2018) menunjukkan bahwa penerapan model pembelajaran kooperatif tipe NHT meningkatkan hasil belajar siswa pada materi kimia di Kelas XI IPA 3 SMA Srijaya Negara Palembang. Peningkatan hasil belajar siswa dapat dilihat dari persentase siswa yag tuntas belajar pada setiap siklus. Pada siklus I siswa yang tuntas belajar sebanyak $40,8 \%$; pada siklus II siswa yang tuntas belajar meningkat menjadi $66,7 \%$; dan pada siklus III siswa yang tuntas belajar meningkat lagi menjadi $88,9 \%$.

Berdasarkan uraian di atas, diketahui bahwa masih banyak siswa Kelas X SMA Negeri 10 Ambon mengalami kesulitan dalam memahami materi ikatan kimia. Hal ini berdampak pada pencapaian hasil belajar siswa dimana sebagian besar siswa tidak tuntas belajar. Untuk meningktkan hasil belajar siswa pada materi ikatan kimia, maka perlu menerapkan model pembelajaran kooperatif tipe NHT berbantuan modul. 


\section{METODE PENELITIAN}

Penelitian ini bertipe deskriptif kuantitatif yakni penelitian yang dilakukan untuk menggambarkan atau menjelaskan secara sistematis dan faktual, mengenai fakta dan sifat populasi tertentu (de Sirat, 2013). Populasi dalam penelitian ini adalah semua Kelas X SMA Negeri 10 Ambon, sampel penelitian adalah siswa Kelas $\mathrm{X}_{2}$ MIA berjumlah 30 siswa. Variabel dari penelitian ini adalah variabel tunggal yakni peningkatan hasil belajar setelah diterapakan model pembelajaran kooperatif tipe Numbered Head Together (NHT) berbantuan modul. Instrumen yang digunakan pada penelitian yaitu: tes (soal tes awal dan tes akhir), lembar pengamatan (afektif, dan psikomotor).

Teknik Analisis Data: Untuk mengetahui hasil belajar pada aspek afektif, psikomotor, dan kognitif digunakan rumus:

$$
\text { Nilai }=\frac{\text { jumlah skor yang dicapai siswa }}{\text { skor maksimal }} \times 100
$$

(Nurlatifah \& Yonata, 2014)

Selanjutnya nilai yang diperoleh dikonversikan menggunakan KKM mata pelajaran kimia dengan kriteria ketuntasan:

\begin{tabular}{ccc}
\hline $\begin{array}{c}\text { Tingkat Penguasaan } \\
\text { Materi }\end{array}$ & Nilai Huruf & Klasifikasi \\
\hline $89-100$ & A & Sangat baik \\
$77-88$ & B & Baik \\
$65-76$ & C & Cukup \\
$<65$ & D & Kurang/gagal \\
\hline
\end{tabular}

Sedangkan peningkatan hasil belajar diperoleh melalui perhitungan nilai N-Gain menggunakan rumus hake sebagai berikut:

Keterangan:

$$
\mathrm{N}-\text { Gain }=\frac{\text { Spoot }- \text { Spre }}{\text { Smaks Spres }}
$$

Spost : Skor posttest

Spre : Skor Pretest

Smaks : Skor Maksimum Ideal

Dengan kriteria:

\begin{tabular}{lc}
\hline Interval & Kategori \\
\hline $\mathrm{G}>0,7$ & Tinggi \\
$0,3<\mathrm{g} \leq 0,7$ & Sedang \\
$\mathrm{G} \leq 0,3$ & Rendah \\
\hline
\end{tabular}

\section{HASIL PENELITIAN}

\section{A. Tes Awal (Pre test)}

Tes awal dilakukan dengan tujuan untuk mengetahui kemampuan awal siswa mengenai materi ikatan kimia. Tes awal terdiri dari 10 soal pilihan ganda (PG) dan 4 soal essai yang disusun 
berdasarkan materi yang akan diajarkan yakni katan ion, ikatan kovalen, ikatan logam dan bentuk molekul. Data hasil belajar pada tes awal ditunjukan pada Tabel 1:

Tabel 1. Data Pencapaian Siswa pada Tes Awal (pre test)

\begin{tabular}{cccc}
\hline Interval & Frekuensi & $\begin{array}{c}\text { Frekuensi } \\
\text { Relatif }(\%)\end{array}$ & Kualifikasi \\
\hline $\mathbf{8 9 - 1 0 0}$ & - & - & Sangat Baik \\
$\mathbf{7 7 - 8 8}$ & - & - & Baik \\
$\mathbf{6 5 - 7 6}$ & - & - & Cukup \\
$<65$ & 30 & 100 & Kurang/Gagal \\
\hline Jumlah & 30 & 100 & \\
\hline
\end{tabular}

Berdasarkan data pada Tabel 1, kemampuan siswa dalam menjawab setiap soal masih rendah dimana $30(100 \%)$ siswa mendapatkan kualifikasi kurang. Hal ini disebabkan karena materi ikatan kimia belum penah diajarkan kepada siswa dan kurangnya kesiapan siswa untuk mengikuti proses pembelajaran. Hasil penelitian ini sejalan dengan pendapat Suryosubroto (2002) yang menyatakan bahwa perkiraan nilai yang akan diperoleh pada tes awal adalah nol atau hanya sedikit saja yang menjawab dengan betul.

\section{B. Hasil Belajar Siswa Selama Proses Pembelajaran}

1. Penilaian Kognitif Siswa

Penilaian aspek kognitif siswa disajikan pada Tabel 2 berikut.

Tabel 2. Data Kemampuan Kognitif Siswa dalam Proses Pembelajaran

\begin{tabular}{|c|c|c|c|c|c|c|c|}
\hline \multirow[t]{2}{*}{ Nilai } & \multicolumn{2}{|c|}{$\begin{array}{l}\text { Pertemuan } \\
\text { I }\end{array}$} & \multicolumn{2}{|c|}{$\begin{array}{l}\text { Pertemuan } \\
\text { II }\end{array}$} & \multicolumn{2}{|c|}{$\begin{array}{l}\text { Pertemuan } \\
\text { III }\end{array}$} & \multirow[t]{2}{*}{ Kualifikasi } \\
\hline & Frekuensi & $\%$ & Frekuensi & $\%$ & Frekuensi & $\%$ & \\
\hline $89-100$ & 5 & 16.7 & 10 & 33.3 & 15 & 50 & Sangat Baik \\
\hline $77-88$ & 10 & 33.3 & 11 & 36.7 & 10 & 33.3 & Baik \\
\hline $65-76$ & 10 & 33.3 & 9 & 30 & 5 & 16.7 & Cukup \\
\hline$<65$ & 5 & 16.7 & - & 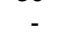 & - & - & Kurang/Gagal \\
\hline Jumlah & 30 & 100 & 30 & 100 & 30 & 100 & \\
\hline
\end{tabular}

Berdasarkan Tabel 2, pada pertemuan pertama terdapat 5 siswa (16.7\%) mendapatkan kualifikasi sangat baik, dan 10 siswa (33.3\%) mendapatkan kualifikasi baik. Pada kualifikasi cukup terdapat 10 siswa (33.3\%); dimana siswa yang mendapatkan kualifikasi cukup belum dapat menyelesaikan soal tentang pembentukan ikatan ion dan ikatan rangkap. Pada kalifikasi kurang terdapat 5 siswa (16.7\%); siswa ini belum mampu menyelesaikan soal-soal pada modul dengan baik. Pertemuan pertama membahas dua indokator yaitu: (1) menjelaskan pengertian dan proses pembentukan ikatan ion, dan (2) menjelaskan proses pembentukan ikatan kovalen tunggal, dan ikatan kovalen rangkap. Bedasarkan hasil evaluasi pertemuan pertama, maka untuk meningkatkan pemahaman siswa terkait proses pembentukan ikatan ion dan proses pembentukan ikatan rangkap, maka guru membahas kembali soal-soal dalam modul khususnya soal-soal yang tidak dapat diselesaikan oleh siswa. Guru juga memberikan bimbingan bahwa kerjasama kelompok turut menentukan keberhasilan siswa, sehingga diperlukan kerjasama yang baik dalam kelompok untuk mempelajari materi pada modul menyelesaikan soal-soal latihan pada modul.

Pada pertemuan kedua, terdapat 10 siswa (33.3\%) mendapatkan kualifikasi sangat baik, dan 11 siswa (36.7\%) mendapatkan kualifikasi baik, serta 9 siswa $(30 \%)$ mendapatkan kualifikasi cukup. Pertemuan kedua membahas dua indikator yaitu: (1) membedakan ikatan kovaalen dan 
ikatan kovalen koordinasi, dan (2) membedakan senyawa polar dan non polar. Adapun 9 siswa yang mendapatkan kualifikasi cukup karena mereka belum bisa membedakan ikatan kovalen dan ikatan kovalen koordinasi. Kemampuan kognitif siswa pada pertemuan kedua meningkat dibandingkan pertemuan pertama, karena tidak ada siswa yang mendapatkan kualifikasi kuranga/gagal. Hal ini dikarenakan semua siswa terlibat secara aktif setelah guru memberikan penguatan dan bimbingan pada akhir pertemuan pertama. Penerapan model pembelajaran kooperatif tipe NHT dan penggunaan modul memungkinkan siswa berperan aktif; disamping itu guru melaksanakan fungsinya sebagai fasilitator dengan baik sehingga mempermudah pemahaman siswa atas materi yang disajikan dengan penyediaan informasi dan soal-soal latihan.

Pada pertemuan ketiga, terdapat 15 siswa (50\%) mendapatkan kualifikasi sangat baik, dan 10 siswa (33.3\%) mendapatkan kualifikasi baik, serta 5 siswa (16.7\%) mendapatkan kualifikasi cukup. Pertemuan ketiga membahas tentang ikatan hidrogen, ikatan logam dan ikatan Van der Waals. Adapun 5 siswa yang memperoleh kualifikasi cukup karena memahami dengan baik tentang proses pembentukan senyawa yang melibatkan ikatan hidrogen. Untuk mereduksi hal ini, maka guru menjelaskan kembali tentang proses pembentukan ikatan hirogen.

Secara keseluruhan (dari pertemuan pertama hingga pertemuan ketiga) kemampuan kognitif siswa mengalami peningkatan. Hal ini disebabkan karena guru telah melaksanakan fungsinya dengan baik sesuai langkah-langkah pembelajaran pada model pembelajaran koopeatif tipe NHT; sehingga siswa dapat menyelesaikan soal-soal latihan dengan baik yang dilandasi rasa tanggungjawab dan kerjasama dalam kelompok.

2. Penilaian Afektif siswa

Penilaian aspek afektif siswa disajikan pada Tabel 3 berikut.

Tabel 3. Data Kemampuan Afektif Siswa dalam Proses Pembelajaran

\begin{tabular}{lccccccl} 
Nilai & \multicolumn{2}{c}{$\begin{array}{c}\text { Pertemuan } \\
\text { I }\end{array}$} & \multicolumn{2}{c}{$\begin{array}{c}\text { Pertemuan } \\
\text { II }\end{array}$} & \multicolumn{2}{c}{$\begin{array}{c}\text { Pertemuan } \\
\text { III }\end{array}$} & Kualifikasi \\
\cline { 2 - 5 } & Frekuensi & Frekuensi $\%$ & Frekuensi $\%$ & \\
\hline $89-100$ & 20 & 66.7 & 20 & 66.7 & 23 & 76.7 & \\
$77-88$ & 4 & 13.3 & 6 & 20 & 5 & 16.7 & Sangat Baik \\
$65-76$ & 6 & 20 & 4 & 13.3 & 2 & 6.6 & Cukup \\
$<65$ & - & - & - & - & - & - & Kurang/Gagal \\
\hline Jumlah & 30 & 100 & 30 & 100 & 30 & 100 & \\
\hline
\end{tabular}

Berdasarkan Tabel 3, pada pertemuan pertama tedapat 20 siswa $(66.7 \%)$ mendapatkan kualifikasi sangat baik, dan 4 siswa (13.3\%) mendapatkan kualifikasi baik. Pada kualifikasi cukup terdapat 6 siswa (20\%); hal ini disebabkan karena 6 siswa ini belum melaksanakan dua aspek penilaian afektif dengan baik yaitu keseriusan dalam menyelelesaikan soal dan kerjasama dalam kelompok.

Pada pertemuan kedua, terdapat 20 siswa (66.7\%) mendapatkan kualifikasi sangat baik, dan 6 siswa (20\%) mendapatkan kualifikasi baik, serta 4 siswa (13.3\%) mendapat kualifikasi cukup. Pada pertemuan ketiga, terdapat 23 siswa (76.7\%) mendapatkan kualifikasi sangat baik, dan 5 siswa $(16.7 \%)$ mendapatkan kualifikasi baik, serta 6 siswa (6.6\%) mendapat kualifikasi cukup. Hal ini menunjukkan bahwa terjadi peningkatan kemampuan afektif siswa dimana persentase siswa mendapatkan kualifikasi sangat baik dan baik mengalami peningkatan. Hal ini menunjukkan bahwa siswa telah serius mengikuti proses pembelajaran dan melakukan kerjasama dengan teman-teman kelompoknya untuk menyelesaikan soal-soal latihan. Peningkatan kemampuan afektif ini juga memberikan kontribusi positif pada peningkatan kemampuan kognitif. Hal ini merupakn kontribusi dari pelaksanaan sintaks model pembelajaran kooperatif tipe NHT dalam proses pembelajaran. 
3. Penilaian Aspek Psikomotor Siswa

Penilaian aspek psikomotor siswa disajikan pada Tabel 4 berikut.

Tabel 4. Data Kemampuan Psikomotor Siswa dalam Proses Pembelajaran

\begin{tabular}{|c|c|c|c|c|c|c|c|}
\hline \multirow[t]{2}{*}{ Nilai } & \multicolumn{2}{|c|}{$\begin{array}{c}\text { Pertemuan } \\
\text { I }\end{array}$} & \multicolumn{2}{|c|}{$\begin{array}{l}\text { Pertemuan } \\
\text { II }\end{array}$} & \multicolumn{2}{|c|}{$\begin{array}{l}\text { Pertemuan } \\
\text { III }\end{array}$} & \multirow[t]{2}{*}{ Kualifikasi } \\
\hline & Frekuensi & i $\%$ & Frekuensi & i \% & Frekuensi & $\%$ & \\
\hline $89-100$ & 20 & 66.7 & 20 & 66.7 & 23 & 76.7 & Sangat Baik \\
\hline 77 - 88 & 4 & 13.3 & 6 & 20 & 5 & 16.7 & Baik \\
\hline $65-76$ & 6 & 20 & 4 & 13.3 & 2 & 6.6 & Cukup \\
\hline$<65$ & - & - & - & - & - & - & Kurang/Gagal \\
\hline Jumlah & 30 & 100 & 30 & 100 & 30 & 100 & \\
\hline
\end{tabular}

Berdasarkan Tabel 4, pada pertemuan pertama tedapat 20 siswa (66.7\%) mendapatkan kualifikasi sangat baik, 4 siswa (13.3\%) mendapatkan kualifikasi baik, dan 6 siswa (20\%) mendapatkan kualifikasi cukup. Pada pertemuan kedua, terdapat 20 siswa (66.7\%) mendapatkan kualifikasi sangat baik, dan 6 siswa (20\%) mendapatkan kualifikasi baik, serta 4 siswa $(13.3 \%)$ mendapat kualifikasi cukup. Pada pertemuan ketiga, terdapat 23 siswa $(76.7 \%)$ mendapatkan kualifikasi sangat baik, dan 5 siswa (16.7\%) mendapatkan kualifikasi baik, serta 6 siswa $(6.6 \%)$ mendapat kualifikasi cukup. Kemampuan psikomotor yang dinilai selama proses pembelajaran adalah kemampuan psikomotor halus yaitu: (1) kemampuan siswa menjelaskan proses terbentuknya ikatan ionik, ikatan kovalen, ikatan logan, dan ikatan Van der Waals; (2) kemampuan siswa mempresentasikan hasil kerja kelompok; dan (3) kemampuan siswa memberikan jawaban/tanggapan terhadap pertanyaan yang diajukan guru dan siswa.

Hasil penilaian aspek psikomotor pada Tabel 4 menunjukkan bahwa terjadi peningkatan aspek psikomotor pada setiap pertemuan. Hal ini berbanding lurus dengan hasil penilaian aspek kognitif dan aspek afektif yang disajikan pada Tabel 2 dan Tabel 3. Hal ini menunjukkan bahwa penerapan model pembelajaran kooperatif tipe NHT berhasil meningkatkan hasil belajar siswa pada aspek kognitif, afektif, dan psikomotor selama proses pembelajaran. Hasil penelitian ini sejalan dengan pendapat Trianto (2009) yang menyatakan bahwa model pembelajaran kooperatif tipe Numbered Head Together (NHT) dirancang untuk melibatkan lebih banyak siswa dalam menelaah materi yang tercakup dalam suatu pelajaran dan mengecek pemahaman mereka terhadap isi pelajaran tersebut. Model pembelajaran kooperatif tipe NHT merupakan variasi dari diskusi kelompok dan saling bekerjasama dalam mengatasi masalah pelajaran pada materi yang kurang dimengerti, siswa dapat saling memberikan pendapat untuk menyelesaikan masalah tersebut dan dapat meningkatkan motivasi yang lebih besar dari pada pembelajaran yang dilakukan secara individu.

\section{Tes Akhir (Post Test)}

Hasil tes akhir disajikan pada Tabel 5 berikut.

Tabel 5. Data Pencapaian Siswa pada Tes Akhir (Post test)

\begin{tabular}{cccc}
\hline Interval & Frekuensi & Frekuensi relatife \% & Kualifikasi \\
\hline $89-100$ & 12 & 40 & SangatBaik \\
$77-88$ & 10 & 33.3 & Baik \\
$65-76$ & 6 & 20 & Cukup \\
$<65$ & 2 & 6.7 & Kurang/Gagal \\
& & & \\
\hline Jumlah & 30 & 100 & \\
\hline
\end{tabular}


Hasil tes akhir pada Tabel 5 menunjukan bahwa 12 siswa (40\%) mendapatkan kualifikasi sangat baik, 10 siswa (33.3\%) mendapatkan kualifikasi baik, 6 siswa $(20 \%)$ mendapatkan kualifikasi cukup, dan 2 siswa (6.7\%) mendapatkan kualifikasi kurang/gagal. Hal ini menunjukkan bahwa penerapan model pembelajaran kooperatif berhasil menghantarkan siswa mencapai ketuntasan belajar sebanyak $93.3 \%$ (kualifikasi sangat baik, baik, dan cukup). Hasil penelitian ini merupakan kontribusi dari penerapan model pembelajaran kooperatif tipe NHT dimana salah satu keunggulan pembelajaran kooperatif tipe NHT adalah dengan sistem penomoran yang memungkinkan setiap anggota dari kelompok berusaha untuk membahas jawaban atas pertanyaan yang diberikan sehingga setiap siswa aktif dalam pembelajaran. Setiap anggota kelompok mempunyai tanggungjawab dan kesempatan yang sama dalam mempresentasikan jawaban yang dihasilkan kelompoknya. Disamping itu modul menyajikan sejumlah informasi dan soal-soal latihan yang memungkin siswa dapat belajar mandiri secara maksimal sehingga berpengaruh terhadap peningkatan pengetahuan siswa pada materi ikatan kimia.

Adapun 2 siswa $(6.7 \%)$ mendapatkan kualifikasi kurang/gagal karena belum mampu menyelesaikan soal-soal yang memiliki kompleksitas/tingkat kesukaran yang tinggi. Soal-soal dimaksud terkait pembentukan ikatan ionik dan pembentukan ikatan kovalen koordinasi; dan untuk meningkatkan pemahaman kedua siswa tersebut guru menugaskan siswa dari kelompok asalnya menjelaskan kepada kedua siswa tersebut cara menyelesaikan soal-soal dimaksud.

\section{Peningkatan Hasil Belajar (N-Gain)}

Berdasarkan perolehan skor tes awal dan tes akhir, maka dilakukan perhitungan nilai $\mathrm{N}$-Gain dan hasilnya ditampilkan pada Tabel 6 berikut:

Tabel 6. Data Peningkatan Hasil Belajar Siswa

\begin{tabular}{|c|c|c|c|}
\hline $\begin{array}{c}\text { Besarnya } \\
\text { g }\end{array}$ & Frekuensi & $\begin{array}{l}\text { Frekuensi } \\
\text { relatif (\%) }\end{array}$ & Interpretasi \\
\hline $\begin{array}{c}\mathbf{g}>0,7 \\
0,3<\mathrm{g} \leq 0,7 \\
\mathbf{g} \leq 0,3\end{array}$ & $\begin{array}{l}18 \\
12 \\
-\end{array}$ & $\begin{array}{l}60 \% \\
40 \% \\
-\end{array}$ & $\begin{array}{c}\text { Tinggi } \\
\text { Sedang } \\
\text { Rendah }\end{array}$ \\
\hline Jumlah & 30 & 100 & \\
\hline
\end{tabular}

Hasil perhitungan nilai $\mathrm{N}$-gain pada Tabel 6 menunjukkan bahwa peningkatan hasil belajar siswa adalah sebagai berikut: 18 siswa (60\%) ada pada kotegori tinggi dan 12 siswa $(40 \%)$ ada pada kategori sedang. Secara keseluruhan, peningkatan hasil belajar siswa pada materi ikatan kimia sebesar 0,71 termasuk dalam kategori tinggi. Hasil ini menunjukan bahwa penerapan modep pembelajaran kooperattf tipe NHT (numbered heads together) berbantuan modul berhasil meningkatkan hasil belajar siswa pada semuan aspek (kognitif, afektif, dan psikomotor).

\section{KESIMPULAN}

Berdasarkan hasil penelitian dan pembahasan, maka dapat disimpulkan bahwa penerapan model pembelajaran kooperatif tipe NHT (numbered heads together) berbantuan modul berhasil meningkatkan hasil belajar siswa kelas X SMA Negeri 10 Ambon pada materi Ikatan Kimia. Hal ini terlihat perolehan tes akhir dimana 12 siswa (40\%) mendapatkan kualifikasi sangat baik, 10 siswa $(33.3 \%)$ mendapatkan kualifikasi baik, 6 siswa $(20 \%)$ mendapatkan kualifikasi cukup, dan 2 siswa $(6.7 \%)$ mendapatkan kualifikasi kurang. Perolehan nilai $\mathrm{N}$-gain adalah 18 siswa $(60 \%)$ berada pada kategori tinggi dan 12 siswa $(40 \%)$ berada pada kategori sedang. Hasil analisis skor gain ternormalisasi rata-rata seluruh siswa sebesar 0,71 berada pada kategori tinggi. Dengan demikian penerapan model pembelajaran kooperati tipe NHT berbantuan modul meningkatkan hasil belajar siswa. 


\section{DAFTAR PUSTAKA}

Anggraini, T.P., Abdurrachman, F., Ibrahim, R. (2018). Penerapan Model Pembelajaran Kooperatif Tipe Numbered Head Together (NHT) Untuk Meningkatkan Hasil Belajar Materi Kimia Siswa Kelas XI IPA 3 SMA Srijaya Negara Palembang. Jurnal Penelitian Pendidikan Kimia: Kajian Hasil Penelitian Pendidikan Kimia, Vol. 5, No. 2, 2018.

De Sirat Hingzty Natalia. (2013). Peningkatan Hasil Belajar Peserta Didik Kelas X SMK Negeri 6 Ambon Menggunakan Model Pembelajaran Kooperatif Tipe Numbered Heads Together (NHT) Dengan Media Flash Player Pada materi Ikatan Kimia. Skripsi: Ambon: Universitas Pattimura

Kemendikbud. (2013). Permendikbud No.64 tentang Standar Isi Pendidikan Dasar dan Menengah. Jakarta: Kementerian Pendidikan dan Kebudayaan

Manurung, I. W., Mulyani, B., \& Saputro, S. (2013). Pengaruh Penggunaan Model Pembelajaran Kooperatif Numbered Head Together (NHT) Dan Learning Together (LT) Dengan Melihat Kemampuan Memori Siswa Terhadap Prestasi Belajar Siswa Pada Materi Tata Nama Senyawa Kimia Kelas X SMA Negeri 2 Karanganyar Tahun 2012/2013. Jurnal Pendidikan Kimia (JPK), Vol. 2 No. 4, 24-31

Ningsih, T. W. (2012). Pengaruh Penggunaan Modul Sejarah Terhadap Prestasi Belajar Siswa Kelas VIII Di SMP Negeri 1 Kesamben Jombang Semester Gasal Tahun Ajaran 2011/2012. (Skripsi). Universitas Negeri Malang

Nurlatifah, S., dan Yonata, B. (2014). Keterampilan Berpendapat Siswa Kelas XI IPIMIES Surabaya Melalui Model Pembelajaran Kooperatif Berbasis Pendekatan Contextual Teaching and Learning (CTL) pada Materi Pokok Laju Reaksi. Unesa Journal of Chemistry Education, 3, 61-69.

Retnani, F, Y., Sukardjo, J, S., \& Utomo, S, B. (2014). Penerapan Metode Numbered Heads Together (NHT) Disertai Macromedia Flash Untuk Meningkatkan Motivasi Dan Prestasi Belajar Siswa Materi Struktur Atom, Sistem Periodik, Dan Ikatan Kimia Kelas XI Ipa4 SMA Negeri 2 Boyolali Tahun Pelajaran 2013/2014. Jurnal Pendidikan Kimia (JPK), Vol. 3 No. 3, 57-65.

Septianingrum Resti. (2014). Penerapan Metode Numbered Heads Together (NHT) Disertai Media Tekateki Silang Untuk Meningkatkan Kemampuan Memori Dan Prestasi Belajar Kimia Pada Materi Sistem Koloid Kelas XI IPA 2 SMA Negeri 2 Karanganyar. Jurnal Pendidikan Kimia Vol. 3 No. 1 Tahun 2014 Hal. 31-36 ISSN 2337-9995

Sulfiani Ridha. (2016). Penerapan Model Pembelajaran Kooperatif Tipe Numbered Head Together (NHT) Untuk Meningkatkan Hasil Belajar Kimia Siswa Kelas XI IPA1 SMA Negeri 3 Watampone (Studi pada Materi Pokok Struktur Atom, Sistem Periodik Unsur dan Bentuk Molekul). Jurnal Chemica VoL. 17 Nomor 1 Juni 2016, 1- 13

Sumarni Woro. (2010). Penerapan Learning Cycle Sebagai Upaya Meningkatkan Ketrampilan Generik Sains Inferensial Logika Mahasiswa Melalui Praktikum Kimia Dasar. Jurnal Fisika Vol 7(1) 52-531.

Supardi, K. I., \& Putri, I, R. (2010). Pengaruh Penggunaan Artikel Kimia Dari Internet Pada Model Pembelajaran Creative Problem Solving Terhadap Hasil Belajar Kimia Siswa SMA. Jurnal Inovasi Pendidikan Kimia, Vol.4, No.1, 574-581.

Suryosubroto. (2002). Proses Belajar Mengajar di Sekolah. Wawasan Baru Beberapa Metode Pendukung dan Beberapa Komponen Layanan Khusus. Jakarta: Rineka Cipta.

Trianto. (2009). Mendesain Model Pembelajaran Inovatif Progesif: Konsep, Landasan, dan Implementasinya pada Kurikulum Tingkat Satuan Pendidikan (KTSP). Jakarta: Kencana. 